\title{
SIGNIFICANCE OF AGRICULTURE IN THE ECONOMIC STRUCTURE AND ECONOMIC DEVELOPMENT OF TRANSITION COUNTRIES
}

\begin{abstract}
In this paper, authors aim to show the significance of agriculture in the economic structure and economic development of transition countries. The role of agriculture is undoubtable in the economic development of transition countries particularly because agriculture represents an important branch of economy in former socialist systems, but also of the structural reform in agrarian sector. Special emphasis is placed on the analysis of indicators of significance for agriculture in economic structure and economic development of individual transition countries. The analysis includes transition countries of the EU, Western Balkan countries and the countries of the Commonwealth of Independent States. The analyzed data refers to the period from 1989 until today, with results created for shorter periods for comparison.
\end{abstract}

Keywords: significance of agriculture, economic structure, economic development, transition countries, changes

\section{Introduction}

The subject of research presented in this paper is the position and significance of the agrarian sector in the economic structure and economic development of transition countries. The identification of changes in the position of agriculture in the economic structure and its contribution to the development of individual transition countries represents the main object of this research. Research on the significance of agriculture for the economic development of transition countries is important because of the role agriculture had in former socialist systems, as well as because of the structure of reforms within its agrosystem.

It is assumed that the relative significance of agriculture in transition countries is lesser in later phases of transition, i.e. economic development. For this purpose, indicators of the significance of agriculture in the economic structure and economic development of individual transition economies will be analyzed.

\footnotetext{
1 sjelic@agrif.bg.ac.rs

2 vukasinkolarevic@gmail.com
} 
The analysis includes the following transition countries: 11 new EU member-states ${ }^{3}$ (NMS-11), Western Balkan countries ${ }^{4}$ (WBC) and countries of the Commonwealth of Independent States ${ }^{5}$ (CIS). Data were monitored for the period between 1989 and 2019, but analysis results were created for shorter periods for data consistency, due to relevant data being incomplete or non-existent.

For the purpose of this research, statistical data of both global and regional organizations were analyzed. The majority of data used for indicator calculation was gathered from time series of the World Bank (WB), the Word Trade Organization (WTO), the Organization for Economic Co-operation and Development (OCDE), the EU (Eurostat) and the International Labour Organization (ILO). Databases of national statistics organizations of countries in focus of this research were used as sources for lacking data. The authors obtained needed results by own calculation.

\section{The agrarian sector reform}

If we know that the process of transition in post-socialist countries was started in order to raise efficiency and transition to market economy (Jelić \& Jovanović, 2010, p. 597), we can conclude that the agrarian sector followed a similar process. Structural changes are not easily defined, as they contain multiple interconnected mechanisms (Happe, 2007, p. 5 ). Due to their nature, agrarian structural changes did not impact only the agroindustrial complex, they also pervaded wider rural society and rural economy (Happe, 2007, p. 6). Although complex, the mentioned changes can be systemized into the following categories: land de-collectivization, the privatization of processing capacities, price deregulation, and market liberalization, as well as the formation of efficient institutional structures and implementational mechanisms (Bogdanov, 2004, p.99). It is worth mentioning that these changes were followed by the rural financial market reform (Buchenrieder \& Möllers, 2011 , p. 10). However, in order to be successful, the transition must also include the process of creating a specific social structure (Šljukić, 2004, p. 270). Such a structure should be characterized: “... by the absence of sharp boundaries between social classes/strata, broad middle classes and the presence of intense social mobility" (Šljukić, 2004, p. 270) further believes that the layer of modern farmers should replace the layer of disorganized peasantry.

Buchenrieder and associates (Buchenrieder et al., 2009, p. 290) think that the process of implemented agrarian reforms was diversified more than expected, and that it was influenced by the existing starting positions of this sector in observed countries. The appropriate insight into the successfulness of implemented reforms can be gained using

3 The analysis includes countries which joined the EU from 2004 onwards, with new noncontinental member-states, Cyprus and Malta, being excluded. Hence, the abbreviation NMS-11 will signify the following countries in this paper: Bulgaria, Estonia, Latvia, Lithuania, Hungary, Poland, Romania, Slovakia, Slovenia, Croatia, the Czech Republic.

${ }^{4}$ Western Balkan countries: Albania, North Macedonia, Bosnia and Herzegovina (B\&H), Serbia and Montenegro.

5 The countries of the Commonwealth of Independent States: Azerbaijan, Belarus, Armenia, Kazakhstan, Kirgizstan, Moldova, Russia, Tajikistan and Uzbekistan. 
the analysis of the indicators of significance of agriculture in the economic structure and economic development.

\section{The indicators of significance of agriculture in the economic structure and economic development}

The opinion that the role of agriculture is primarily determined by its position relative to industry and its necessity to provide factors for industrial growth has gradually changed in the 1960s of the last century. As decades went by, research showed that the significance of agriculture was multifold and that, for that reason, it had to be observed as a branch which demands its own development through modernization. This approach required the development of methodological procedures and establishment of certain regularities regarding the position of agriculture within economy.

For years, the contribution of agriculture has been perceived not only through its basic functions, but also through the indicators of its contribution to economic development. Božić and associates (Božić et al., 2011, p.17) distinguish the following indicators as most important: the participation of agricultural population in the overall population, i.e. the proportion of agriculture in the overall employment, the proportion of agriculture in the formation of gross domestic product, the significance of agriculture in foreign trade, the proportion of investments in agriculture in total economic investments, and the proportion of food expenditure in the total personal consumption expenditures. A proper assessment of the significance of agriculture is based on identifying all aspects of modern agriculture, recognized as the creator of national macroeconomic aggregates (Zakić \& Stojanović, 2008).

A significant aspect of the transformation of rural society is reflected in the change of economic structure of society in Serbia. The number of people employed in agriculture has been in decline, which represents a consequence of a positive response to the transformation of economic structure and the privatization of economic system (Drobnjak et al., 2015, p.183).

The following sections display the results of the analysis of previously mentioned indicators and interpretations based on scientifically determined regularities.

\section{The proportion of employment in agriculture relative to total employment}

Employees in the agricultural sector make a significant portion of the total world population. According to ILO estimates, in 2016 agricultural population made about $29 \%$ of all employees in the world, with a tendency of further decline (Key Indicators of the Labour Market, ILO). From the aspect of countries observed in this paper, the mentioned proportion has a steeper tendency of decline compared to the global tendency. This can be characterised as a part of the reform process present in agricultures of transition countries.

Over the past 30 years, transition countries have faced significant limitations in terms of employment of the surplus workforce from agriculture. The inability to redirect the agricultural workforce towards non-agricultural sectors in the countries with weakened 
industries resulted in agriculture becoming the bottleneck of development with its low productivity. The share of agricultural population in the overall population is lowest in countries with highly developed industries. The previous statement is also consistent with the regular occurrence that economic and rural population are being reduced due to economic development (Božić et al., 2011, p. 17). The most developed global economies have under $5 \%$ of agricultural employment, while this rate in member-states of the Organization for Economic Co-operation and Development (OECD) has been $4 \%$ on average in the past decade (Felipe et al., 2014, p. 4).

When it comes to Western Balkan countries, the closest one to the OECD's percentage is Montenegro; this can be explained with its economy which relies on tourism and hospitality industry to a larger extent, but also with less favorable natural conditions for agricultural production. Other countries in the region have a high proportion of agriculture in the total employment, with the highest being in Albania which recorder $72,2 \%$ (Graph 1 at the middle of the observed period (2001). According to the data shown in this paper, this percentage holds the record and is certainly much closer to the most undeveloped countries in the world than to those that are at a higher level of development. In North Macedonia and Serbia, relative levels of agricultural employment are on average five times higher than EU-15 levels (around $4 \%$ in recent years).

Modernization processes in rural areas have produced not only a separation of countrified (traditional) and rural, due to deagrarianization and change of cultural and political patterns, but also a more complete inclusion of agriculture in the social division of labor. Agriculture as a branch of economy ceases to be tied, in a social sense, exclusively to rural areas (Šljukić, 2014, p. 75).

\section{The proportion of agriculture in the formation of gross domestic product (GDP)}

The proportion of agriculture in the formation of gross domestic product (GDP) shows the percentage of GDP coming from the agricultural sector and can therefore be observed as a measure of GDP's dependence on agriculture in a year. The successfulness of agricultural production will have a larger impact on the GDP of countries with a higher proportion of agriculture in GDP. Therefore, the issue of the dependence of GDP decline under the influence of natural factors on agricultural production in a given period may be raised.

When examining the changes of this indicator, other factors that affect the current significance of agriculture are often taken into account. Zakić and Stojanović (Zakić \& Stojanović, 2008, p.161) consider factors that determine the changes in the relative significance of agriculture to be the following: the initial proportion of non-agricultural sectors and the relationship of growth rates between agriculture and non-agricultural sectors. A rapid decrease of the significance of agriculture can lead a country's economy into a poor position. An unbalanced reliance on non-agricultural sectors, while neglecting agriculture as a source of raw materials and food, can lead a country into a trap where agricultural growth is neglected (Zakić \& Stojanović, 2008, p.163) which hinders its economic growth.

In WBC Graph 2, the observed indicator was continuously highest in Albania, and it was at a high level $(22,65 \%)$ at the end of the observed period. In Serbia and B\&H, the 
proportion of agriculture in GDP more than halved in the period between 1993 and 2017, and it currently sits at below 10\%. North Macedonia and Montenegro share a common characteristic, i.e. the observed indicator didn't significantly change, and it has varied in the interval between $9 \%$ and $14 \%$ since 2000 .

New EU member-states' agricultures have a lesser relative significance for GDP in these countries (below 5\%), while this indicator has been shifting between $8 \%$ and $10 \%$ on average in the last 15 years in WBC.

\section{The significance of agriculture in foreign trade}

The role of agriculture in foreign trade is determined primarily by natural conditions and the country's economic policy. In short, the extent to which agriculture will contribute to the collection of foreign exchange assets from abroad depends on viewing eventual export advantages of this sector. Zakić (Zakić, 2008, p.174) thinks that, when reorienting production and export structure of goods, marginal costs of import substitution should be taken into account and adds that the optimal point of agricultural export can hardly be found, due to uncertainties characterizing this problem.

In order to understand the effects of transition on foreign trade of agricultural products in transition countries, graphs were used to represent five-year-long processes of import and export, along with the balance of foreign trade of agricultural products ${ }^{6}$ in the period between 2003 and 2017 Graphs 3 and 4. By comparing the values of import and export of agricultural products, we can identify differences in tendencies and dynamics during the transition period. On the other hand, insight into the balance of foreign trade of agricultural products enables us to determine the position of a country as a net exporter or net importer of agricultural products. It ought to be mentioned that re-export was included in export values calculation.

The most significant export of agricultural products of all WBC was recorded in Serbia, with a five-year average foreign balance after 2012 being around 1,4 billion dollars (Graph 3). This data shows a significant increase of export of this group of products. All countries, except Serbia, had a significantly higher import values compared to their export of agricultural products, which contributed to the fact that WBC, as a group, recorded a net deficit of foreign trade of agricultural products in the period between 2003 and 2017 Graph 3. This deficit was lower in the period between 2013 and 2017, compared to the previous ten-year period, primarily due to a distinctive growth of net surplus recorded in Serbia (around 700 million dollars annually), the only net exporter among WBC. As for other countries, their import dependence of agricultural products grew in the observed period. In most WBC, a balanced growth rate of agricultural export within total export was identified, with relatively small variations Graph 4) Montenegro, where the indicator in question reached an increase rate of almost 14 percentage points in one decade, is an exception.

${ }^{6}$ According to the Standard International Trade Classification (SITC), agricultural products are distributed into SITC sections $0,1,2$, and 4, with the exception of SITC divisions 27 and 28. See more in: http://unstats.un.org/unsd/cr/registry/regcst.asp?Cl=14, accessed on $26^{\text {th }}$ March 2019. 


\section{The proportion of agricultural investments in the total economic investments}

Investments in agriculture represent only a small portion of total economic investments for most transition countries. However, their significance is multifold. Along with creating conditions for the improvement of agricultural production, agricultural investments can contribute to wider social interests. These investments are often activated in order to mitigate the effects of poverty and to employ surplus workforce. If current human-caused environmental degradation via agriculture is taken into account, potential investments that respect sustainable management of natural resources will significantly contribute to sustainable economic development. Necessary investments in agriculture are often lacking or are slower than those in other branches of economy, due to a slower capital turnover specific for agriculture. Economic power of agriculturists is often insufficient for the use of accumulated monetary assets. The issue of adequate participation of financial organizations in rural areas of transition countries during the initial phases of transition can be raised as well. Financial limitations can also be imposed by creditors, in the shape of demands for collateral insurance (Happe, 2007, p.10). Buchenrieder and Möllers (Buchenrieder \& Möllers, 2011, pp.10-11) assert that financial system reform in the transition period was followed by problems of irresponsible bank operation, reflected in financing loss-making state-owned companies, in addition to the lack of effective control and the lack of development of financial intermediation in rural economy, and therefore, agriculture.

For the purpose of this analysis, data from selected European countries ${ }^{7}$ were examined, while CIS countries weren't taken into consideration.

Most examined countries are characterized by the fact that the proportion of agricultural investments in total economic investments is no higher than $4 \%$, with Bulgaria and Estonia being exceptions. In Slovenia, the relative significance of agricultural investments is at the lowest level of all countries, and makes about $0.5 \%$ of total investments in all observed years.

In accordance with determined trends of the observed indicator, it can be concluded that there are certain deviations, and for that reason it is important to perform a deeper analysis of the state of this indicator. Such an analysis would be conducted in order to determine certain regularities and it could imply the analysis of: structure of agricultural investments, country's geographical position, spatial distribution of natural wealth and conditions for modern agricultural production.

\section{The proportion of food expenditure in the total household expenditure for personal consumption}

A high proportion of expenditure for food in the total expenditure represents a significant indicator of reached economic development and standard of living. The popu-

\footnotetext{
7 Nine countries were observed in a ten-year period: three WBC and six NMS. Graph 5 shows the share of agricultural investments in total economic investments, determined using investment data based on activity of investors within statistical reports of national statistics institutions in observed countries.
} 
lation's ability to spend a significant part of its income on other goods can propel the country's economy. In poor and underdeveloped countries, expenditure for food represents the majority of total personal consumption expenditure. "With economic growth and increase of income, the proportion of expenditure for food in the total household expenditure for personal consumption declines" (Božić et al., 2011, p. 21) . $^{\text {. }}$

In Western Balkan countries, the proportion of expenditure for food in the total expenditure for personal consumption is at a high level Table 1. Tendencies of this indicator did not reveal significant changes during the observed period. It is noticeable that this level constantly remains at about 30\%; it is probably even higher in Albania (given the fact that expenditure on non-alcoholic beverages was excluded).

\section{Conclusion}

By analysing a series of indicators, changes in the significance of agriculture in the economic structure of certain transition countries were identified, and appropriate conclusions were made based on these changes. For the period between 1989 and 2019, the following indicators were analysed: the proportion of employment in agriculture in the total employment, the proportion of agriculture in gross domestic product (GDP), the significance of agriculture in foreign trade, the proportion of agricultural investments in total economic investments, the proportion of expenditure for food in the total household expenditure for personal consumption. Countries with high economic dependence on agriculture were identified by indicator analysis.

Based on four indicators applied to 11 new EU member-states (NMS-11), we determined that the relative significance of agriculture diminishes as countries enter later phases of transition. The significance of agriculture in most Western Balkan countries (WBC) and countries of the Commonwealth of Independent States (CIS) is at a high level, even after 30 years of transition. This state can be linked with a lower rate of implemented reforms in comparison to new EU member-states. In accordance with the tempo of transition present in aforementioned regions, it can be concluded that agriculture will retain a significant place in the economies of these countries in following years. Due to the lack of data and thus the lack of a proper analysis of the fifth indicator, i.e. the proportion of agricultural investments in total economic investments, no conclusions were reached based on this parameter.

Measured by analyzed indicators, the significance of agriculture in the economic structure and the economic development of Serbia is high. By observing the proportion of employment in agriculture in the total employment, which exceeds $20 \%$, a high dependence of Serbian economy on its agriculture was determined. Approximately the same proportion was recorded in terms of export of agricultural-food products in the total Serbian export. The proportion of expenditure for food is relatively equal to the levels of other Western Balkan countries, but it still remains extremely high (between 13 and 15 percentage points in relation to EU average). The proportion of agriculture in gross domestic product (GDP) is an exception from these tendencies. This indicator has been in constant decline over the past 20 years, and today it sits at 5\%. Would this decline be interpreted in the same way if we assumed that economic sanctions and war caused the agrarianiza-

${ }^{8}$ First Engel's Law 
Sreten M. Jelić, Vukašin Ž. Kolarević, Significance of Agriculture in the Economic Structure...

tion of Serbian economy in the 1990s? This case further confirms the necessity for a more versatile analysis and monitoring of socio-economic trends in order to understand the position of agriculture in the economies of transition countries.

In order to fully understand the indicators, in future research it is necessary to make deeper comparisons between countries possessing relatively similar indicators in order to determine whether the position of agriculture in these countries is a reflection of an (un) developed economy or the country's economic policy. 
Сретен М. Јелић ${ }^{1}$

Вукашин Ж. Коларевић 2

Универзитет у Београду

Пољопривредни факултет

Београд (Србија)

\title{
ЗНАЧАЈ ПОЉОПРИВРЕДЕ У ПРИВРЕДНОЈ СТРУКТУРИ И ПРИВРЕДНОМ РАЗВОЈУ ЗЕМАЉА У ТРАНЗИЦИЈИ
}

\author{
(Превоg In Extenso)
}

Сажетак: У овом раду циљ аутора је да укажу на значај пољопривреде у економској структури и за економски развој земаља у транзицији. Када је у питању развој земаља у транзицији, улога пољопровреде је неспорна, нарочито због тога што пољопривреда представља важну грану економије бивших социјалистичких система, али и структурних реформи аграрног сектора. Посебан нагласак је на анализи показатеља значаја пољопровреде у привредној структури и за привредни развој појединих земаља у транзицији. Анализа обухвата земље ЕУ које су у транзицији, земље Западног Балкана и државе чланице Заједнице независних држава. Анализирани подаци односе се на период од 1989. до данас, а резултати су креирани за краће периоде ради поређења.

Кључне речи: значај пољопривреде, економска структура, економски развој, земље у транзицији, промене

\section{Увод}

Предмет истраживања овог рада је положај и значај аграрног сектора у привредној структури и привредном развоју транзиционих земаља. Утврђивање промена у позицији пољопривреде у привредној структури и њеном доприносу привредном развоју појединих транзиционих земаља, представља основни циљ у овом истраживању. Испитивање значаја пољопривреде за привредни развој транзиционих земаља је важно због улоге коју је пољопривреда имала у бившим социјалистичким системима, као и због структуре реформи унутар њеног агросистема.

Претпоставља се да је релативни значај пољопривреда транзиционих земаља мањи у каснијим фазама транзиције, односно привредног развоја. У ову сврху биће извршена анализа индикатора значаја пољопривреде у привредној структури и привредном развоју појединих транзиционих економија.

\footnotetext{
1 sjelic@agrif.bg.ac.rs

2 vukasinkolarevic@gmail.com
} 
Сретен М. Јелић, Вукашин Ж. Коларевић, Значај йолойривреgе у йривреgној...

Анализом су обухваћене транзиционе земље: 11 нових земаља чланица ${ }^{3}$ ЕУ (НЗЧ-11), земље Западног Балкана ${ }^{4}$ (З3Б) и земље Заједнице независних држава 5 (ЗНД). Подаци су праћени за период од 1989. до 2019. године, с тим да су резултати анализа креирани за краће периоде ради поштовања конзистентности података, услед непотпуности или непостојања релевантних података.

За потребе истраживања, анализирани су статистички подаци светских, али и регионалних организација. Највећи део података за обрачун индикатора прикупљен је из временских серија Светске банке $(W B)$, Светске трговинске организације (WTO), Организације за економску сарадњу и развој (OECD), ЕУ (Eurostat) и Међународне организације рада (ILO). Као извор за недостајуће податке, коришћене су базе података националних статистичких организација земаља које су биле у фокусу овог рада. Аутор је самосталним обрачуном дошао до одговарајућих резултата.

\section{Реформа аграрног сектора}

Уколико се зна да је процес транзиције у постсоцијалистичким земљама започет ради подизања ефикасности и преласка на тржишну привреду (Jelić \& Jovanović, 2010, str.597), може се закључити да је сличан процес пратио аграрни сектор. Структурне промене не могу се лако дефинисати, јер оне садрже вишеструке међусобно повезане механизме (Нарре, 2007, str. 5). Услед таквог деловања, структурне промене у аграру нису утицале само на агроиндустријски комплекс, већ су се прожимале и на шире рурално друштво и руралну економију (Нарре, 2007, str. 6). Иако сложене, поменуте промене се могу систематизовати на следеће: деколективизацију земљишта, приватизацију прерађивачких капацитета, дерегулацију цена и либерализацију тржишта, као и формирање ефикасних институционалних структура и имплементационих механизама (Bogdanov, 2004, str. 99). Претходном вреди додати да је поменуте промене пратила и реформа руралног финансијског тржишта (Buchenrieder \& Möllers, 2011, str. 10). Ипак, да би се сматрала успешном, транзицијом мора бити обухваћен и процес креирања специфичне друштвене структуре (Šljukić, 2004, str. 270). Овакву структуру би требало да одликују: „...одсуство оштрих граница између друштвених класа/слојева, широки средњи слојеви и присуство интензивне друштвене покретљивости“ (Šljukić, 2004, str. 270), који даље сматра да би слој дезорганизованог сељаштва, требао да замени слој модерних пољопривредника.

Бухенридерова и сарадници (Buchenrieder et al., 2009, str. 290) сматрају да је процес спроведених реформи у аграру био диверзификован више него што се очекивало и да је то утицај тадашњих почетних позиција овог сектора у посматраним земљама.

3 Анализом су обухваћене земље које су приступиле ЕУ од 2004. године па надаље, при чему су из посматрања изузете неконтиненталне нове земље чланице, Кипар и Малта. Дакле, у овом раду ће се под скраћеницом НЗЧ-11 подразумевати скуп следећих држава: Бугарска, Естонија, Летонија, Литванија, Мађарска, Пољска, Румунија, Словачка, Словенија, Хрватска, Чешка.

4 Земље Западног Балкана: Албанија, Северна Македонија (CM), Босна и Херцеговина (БиХ), Србија и Црна Гора.

5 Земље Заједнице независних држава: Азербејџан, Белорусија, Јерменија, Казахстан, Киргистан, Молдавија, Русија, Таџикистан и Узбекистан. 
Одговарајући увид у успешност спроведених реформи може се остварити анализом индикатора значаја пољопривреде у привредној структури и привредном развоју.

\section{Индикатори значаја пољопривреде у привредној структури и привредном развоју}

Становиште да је улога пољопривреде превасходно одређена њеним положајем према индустрији и неопходношћу пољопривреде да приушти факторе за индустријски развој, постепено се мењало од шездесетих година прошлог века. С протоком деценија увиђало се на основу истраживања аутора да је значај пољопривреде вишеструк и да се управо из тог разлога мора посматрати као грана која захтева сопствени развој кроз модернизацију. Овакав приступ је захтевао развијање методолошких поступака и утврђивање одређених закономерности које се односе на положај пољопривреде у оквиру привреде.

Контрибуција пољопривреде се већ дуги низ година посматра не само кроз њене основне функције, већ и кроз индикаторе њеног доприноса привредном развоју. Божић и сарадници (Božić i dr, 2011, str.17) као најважније издвајају: учешће пољопривредног у укупном становништву, односно удео пољопривреде у укупној запослености, учешће пољопривреде у формирању бруто домаћег производа, значај пољопривреде у спољнотрговинској размени, заступљеност инвестиција у пољопривреди у оквиру укупних привредних инвестиција и удео издатака за исхрану у укупним издацима за личну потрошњу домаћинстава. Правилна процена значаја пољопривреде заснива се на уочавању свих аспеката модерне пољопривреде, као ствараоцу националних макроекономских агрегата (Zakić \& Stojanović, 2008).

Значајан аспект трансформације руралног друштва огледа се у промени економске структуре друштва у Србији. Број запослених у пољопривреди бележи пад што је последица позитивног одговора на трансформацију привредне структуре и приватизације привредног система (Drobnjak i dr, 2015, str.183).

У даљем делу рада приказани су резултати анализе претходно наведених индикатора и тумачења на основу научно утврђених закономерности.

\section{Учешће запослених у пољопривреди у укупној запослености}

Запослени у сектору пољопривреде чине значајан део укупног светског становништва. Према проценама $I L O$, пољопривредно становништво у 2016. години чини око 29\% запослених у свету, с даљом тенденцијом пада (Key Indicators of the Labour Market, ILO). Из аспекта земаља посматраних у овом раду, поменуто учешће има бржу тенденцију пада у односу на светску. Ово се може окарактерисати као део реформског процеса који је присутан у пољопривредама земаља у транзицији.

Транзиционе земље су се у претходних 30 година суочавале са значајним ограничењима у смислу запошљавања вишка радне снаге из пољопривреде. Немогућност одлива пољопривредне радне снаге ка непољопривредном сектору у земљама са ослабљеном индустријом, учинила је да пољопривреда постане уско грло развоја са својом ниском продуктивношћу. Учешће пољопривредног у укупном становништву најниже је у земљама с високоразвијеном индустријом. С претходном 
Сретен М. Јелић, Вукашин Ж. Коларевић, Значај йољойривреgе у йривреgној...

тврдњом подудара се и закономерна појава да се са привредним развојем смањује пољопривредно и сеоско становништво (Bоžić i dr, 2011, str. 17). Најразвијеније привреде у свету имају учешће пољопривредне запослености испод 5\%, док је ово учешће на нивоу чланица Организације за економску сарадњу и развој (OECD) у претходној деценији просечно износило 4\% (Felipe et al., 2014, str. 4).

Од земаља Западног Балкана најближа проценту OECD-a јесте Црна Гора, што се може објаснити привредом која се у већој мери ослања на туризам и угоститељство, али и мање повољним природним условима за бављење пољопривредном производњом. Остале земље региона имају високо учешће пољопривреде у укупној запослености, а свакако предњачи Албанија која је на половини посматраног периода транзиције (2001. године) бележила 72,20\% Графикон 1. Према приказаним подацима у раду, овај проценат је рекордан и свакако је ближи најнеразвијенијим земљама света него земљама на вишем степену развијености. У Македонији и Србији релативни нивои пољопривредне запослености су у просеку око 5 пута већи од нивоа ЕУ-15 (око 4\% последњих година).

Модернизацијски процеси у руралним подручјима нису довели само до раздвајања сељачког (традиционалног) и сеоског, услед деаграризације и промене образаца културних и политичких већ и до потпунијег укључивања пољопривреде у друштвену поделу рада. Пољопривреда као привредна грана престаје да буде везана у друштвеном смислу искључиво за рурална подручја (Šljukić, 2014, str. 75).

\section{Учешће пољопривреде у формирању бруто домаћег производа (БДП)}

Учешће пољопривреде у формирању бруто домаћег производа (БДП) приказује колики проценат БДП-а долази из пољопривредног сектора и стога се може посматрати као мера зависности БДП-а од пољопривреде у току једне године. Успешност пољопривредне производње утицаће више на БДП оних земаља са израженим високим учешћем пољопривреде у формирању БДП-а. Може се поставити питање зависности пада БДП-а под утицајем природних фактора на пољопривредну производњу у одређеном периоду.

При разматрању кретања овог индикатора неретко се у обзир узимају и други фактори који утичу на тренутни значај пољопривреде. Закић и Стојановић (Zakić \& Stojanović, 2008, str.161) сматрају да су фактори који одређују кретање стопа релативног значаја пољопривреде: иницијални удео непољопривредног сектора и однос стопа раста пољопривреде и непољопривредног сектора. Убрзано смањење значаја пољопривреде може довести привреду земље у лошу позицију. Неуравнотежено ослањање на непољопривредни сектор уз запостављање пољопривреде као извора сировина и хране, може довести до замке запостављања раста пољопривреде (Zakić \& Stojanović, 2008, str.163) из које следи ограничавање економског раста једне земље.

У оквиру З3Б посматрани индикатор Графикон 2 континуирано је највиши у Албанији и на крају посматраног периода је на високом нивоу $(22,65 \%)$. У Србији и БиХ, учешће пољопривреде у формирању БДП-а је од 1993. до 2017. године и више него преполовљено и тренутно је испод 10\%. За СМ и Црну Гору је заједничко да 
није дошло до значајне промене посматраног индикатора, који од 2000. године варира у интервалу од 9 до $14 \%$.

Пољопривреде нових земаља чланица ЕУ имају мањи релативни значај за формирање БДП-а својих земаља (испод 5\%), док се овај показатељ просечно за ЗНД у последњих 15 година креће између $8 \%$ и 10\%.

\section{Значај пољопривреде у спољнотрговинској размени}

Улога пољопривреде у оквиру спољнотрговинске размене одређена је пре свега природним условима и економском политиком земље. Укратко, у којој мери ће пољопривреда допринети прикупљању девизних средстава из иностранства зависиће од сагледавања евентуалних експортних предности овог сектора. Закић (Zakić, 2008, str.174) сматра да при преоријентацији производње и извозне структуре роба, треба узети у обзир маргиналне трошкове замене увоза и додаје да се оптимална тачка пољопривредног извоза тешко може пронаћи услед неизвесности која карактерише овај проблем.

Ради сагледавања утицаја транзиције на спољнотрговински промет пољопривредних производа транзиционих земаља, приказани су графикони на којима су представљени петогодишњи просеци увоза и извоза, као и салда спољнотрговинске размене пољопривредних производа ${ }^{6}$ у периоду од 2003. до 2017. године Графикони 3 И. Упоредним прегледом вредности извоза и увоза пољопривредних производа уочене су разлике у тенденцијама и динамици током периода транзиције. С друге стране, увид у салдо спољнотрговинске размене пољопривредних производа омогућава одређивање положаја земље као нето извознице или нето увознице пољопривредних производа. Треба напоменути да је у оквиру обрачунатих вредности извоза укључен и реекспорт.

Најзначајнији извоз пољопривредних производа од свих З3Б бележи Србија, чији петогодишњи просек спољнотрговинског салда после 2012. године износи око 1,4 милијарди долара (Графикон 3. Овај податак показује значајан раст извоза ове групе производа. Све земље, изузев Србије, имале су значајно више вредносне нивое увоза у односу на извоз пољопривредних производа, што је допринело да 33Б-а као групација бележе нето дефицит спољнотрговинске размене пољопривредним производима у периоду од 2003. до 2017. године Графикон 3. Овај дефицит је нижи у периоду од 2013. до 2017. године у односу на претходни десетогодишњи период, пре свега због изразитог раста нето суфицита који је забележила Србија (годишње око 700 милиона долара), као јединог нето извозника међу З3Б-а. За остале земље може се констатовати да се у посматраном периоду повећала њихова увозна зависност пољопривредних производа. У већини З3Б уочено је уравнотежено кретање стопе пољопривредног извоза у оквиру укупног извоза, са релативно малим варирањима (Графикон 4). Изузетак је Црна Гора, где је поменути индикатор у периоду од једне деценије достигао раст од скоро 14 процентних поена.

6 По Стандардној међународној трговинској класификацији (SITC), пољопривредни производи су распоређени у SITC секцијама 0, 1, 2 и 4, уз изузимање SITC дивизија 27 и 28. Погледати: http://unstats.un.org/unsd/cr/registry/regcst.asp?Cl=14, приступљено: 26.3.2019. 
Сретен М. Јелић, Вукашин Ж. Коларевић, Значај йолойривреgе у йривреgној...

\section{Заступљеност инвестиција у пољопривреди у укупним привредним инвестицијама}

Инвестиције у пољопривреди већине транзиционих земаља заузимају веома мало учешће у укупним привредним инвестицијама. Ипак, њихов значај је вишеструк. Поред стварања услова за унапређење пољопривредне производње, инвестиције усмерене ка пољопривреди могу допринети ширем, друштвеном интересу. Ове инвестиције често се активирају ради ублажавања ефеката сиромаштва и упошљавања вишка радне снаге. Уколико се узме у обзир и садашње нарушавање животне средине од стране човека кроз пољопривреду, евентуалне инвестиције које уважавају одрживо управљање природним ресурсима значајно ће допринети и одрживом економском развоју. Неопходне инвестиције у пољопривреду често изостају или до њих долази спорије него у другим привредним гранама, сходно специфичности споријег обрта капитала у пољопривреди. Економска снага пољопривредника често је недовољна за ангажовање акумулираних новчаних средстава. Може се поставити и питање одговарајућег учествовања финансијских организација у руралним подручјима транзиционих земаља током иницијалних фаза транзиције. Кредитор може наметнути ограничења у смислу финансирања, кроз захтеве везане за колатерално обезбеђење (Нарре, 2007, str.10). Гертруда Бухенридер и Џуди Мелерс (Buchenrieder \& Möllers, 2011, str.1011) сматрају да су реформу финансијског система у периоду транзиције поред изостанка развијености финансијског посредовања у руралној економији, а самим тим и пољопривреди, пратили и проблеми неодговорног пословања банака које се огледало у финансирању губиташких државних предузећа, као и недостатку ефективне контроле.

За потребе анализе посматрани су подаци одабраног броја европских земаља ${ }^{7}$, док земље ЗНД нису биле предмет анализе.

За већину посматраних земаља карактеристично је да учешће пољопривредних инвестиција у укупним привредним инвестицајама не прелази $4 \%$, док су изузетак Бугарска и Естонија. У Словенији је релативни значај инвестиција у пољопривреди на најнижем нивоу од свих земаља и у укупном учешћу заузима око пола процента у свим посматраним годинама.

Сходно утврђеним кретањима посматраног индикатора може се закључити да постоје одређена одступања и да је из тог разлога важно учинити дубљу анализу при процени стања овог индикатора. Таква анализа би била рађена с циљем утврђивања одређених закономерности и могла би да подразумева анализу: структуре инвестиција у пољопривреди, географског положаја земље, просторне распоређености природних богатстава и услова за бављење модерном пољопривредном производњом.

\footnotetext{
7 Посматран је десетогодишњи период за девет земаља и то: три земље Западног Балкана и шест нових земаља чланица ЕУ. На Графикону 5 приказано је учешће инвестиција у пољопривреди у укупним привредним инвестицијама, које је утврђено кроз податке о инвестицијама на основу делатности инвеститора унутар статистичких извештаја националних статистичких институција посматраних земаља.
} 


\section{Удео издатака за исхрану у укупним издацима за личну потрошњу домаћинстава}

Високо учешће издатака за исхрану у укупним издацима представља значајан показатељ достигнутог степена привредног развоја и животног стандарда. Могућност становништва да значајан део троши и на друге робе, може покренути привреду једне земље. У сиромашним и недовољно развијеним земљама издаци за исхрану имају већинско учешће у укупним издацима за личну потрошњу. „Са привредним развојем и порастом дохотка смањује се учешће издатака за исхрану у укупним издацима за личну потрошњу домаћинстава” (Božić i dr, 2011, str. 21)

У земљама Западног Балкана учешће издатака за исхрану у укупним издацима за личну потрошњу је на високом нивоу Табела 1). Тенденције овог индикатора не показују значајније промене у току посматраног периода. Уочљиво је да се овај ниво константно налази око 30\%, док је у Албанији он вероватно и виши (с обзиром на то да нису урачунати издаци за безалкохолна пића).

\section{Закључак}

Кроз анализу низа индикатора уочене су промене у значају пољопривреде у привредној структури појединих земаља у транзицији и на основу тога донети су одговарајући закључци. За период од 1989. до 2019. године анализирани су следећи индикатори: учешће пољопривреде у укупној запослености, учешће пољопривреде у формирању бруто домаћег производа (БДП), значај пољопривреде у спољнотрговинској размени, заступљеност инвестиција у пољопривреди у укупним привредним инвестицијама, удео издатака за исхрану у укупним издацима за личну потрошњу домаћинстава. Прегледом индикатора препознате су земље с високом зависношћу економије од пољопривреде.

На основу четири обухваћена индикатора примењених на једанаест нових земаља чланица (НЗЧ-11) установљено је да се релативни значај пољопривреде смањује с преласком на касније фазе транзиције. Значај пољопривреде у већини земаља Западног Балкана (З3Б) и чланица Заједнице независних држава (ЗНД) је и после 30 година транзиције на високом нивоу. Овакво стање може се повезати с нижим степеном спроведених реформи у односу на нове земље чланице ЕУ. Сходно темпу транзиције који је присутан на поменутим просторима, може се закључити да ће пољопривреда и у наредним годинама имати значајно место у привредама тих земаља. Услед недостатка података, а самим тим и изостанка одговарајуће анализе петог индикатора, тј. учешћа инвестиција у пољопривреди у укупним привредним инвестицијама није се дошло до одговарајућих закључака по овом параметру.

Мерено анализираним индикаторима значај пољопривреде у привредној структури и привредном развоју Србије је висок. Посматрајући заступљеност запослених у пољопривреди у укупном броју запослених, која премашује $20 \%$, утврђена је висока зависност привреде Србије од пољопривреде. Приближно толики удео забележен је у учешћу извоза пољопривредно-прехрамбених производа у укупном извозу Србије. Учешће издатака за исхрану је релативно уједначено с нивоима других земаља За-

8 Први Енгелов закон 
Сретен М. Јелић, Вукашин Ж. Коларевић, Значај йољойривреgе у йривреgној...

падног Балкана, али и даље изразито високо (између 13 и 15 процентних поена у односу на просек ЕУ). Изузетак од наведених тендеција је учешће пољопривреде у формирању БДП-а Србије. Овај индикатор у последњих 20 година бележи јасан пад, те се данас налази на нивоу од 5\%. Да ли би се овај пад тумачио на исти начин, уколико се претпостави да су економска блокада државе и ратови условили аграризацију српске привреде током деведесетих година? И овај случај потврђује неопходност свестраније анализе и праћења друштвено-економских кретања ради разумевања положаја пољопривреде у привредама транзиционих земаља.

Ради потпуног разумевања индикатора у будућим истраживањима је потребно направити дубље компарације између земаља које поседују релативно сличне показатеље, да би се установило да ли је положај пољопривреде у тим земљама одраз (не)развијености привреде или економске политике коју води одређена земља.

\section{REFERENCES / ЛИТЕРАTУРA}

Bogdanov, N. (2004). Agriculture in international integration and the position of Serbia. Beograd: Društvo agrarnih ekonomista Jugoslavije. [In Serbian]

Božić, D., Bogdanov, N., Ševarlić M. (2011). Economics of agriculture. Beograd: Poljoprivredni fakultet Univerziteta u Beogradu. [In Serbian]

Buchenrieder, G., Hanf, J. H., \& Pieniadz, A. (2009). 20 Years of Transition in the AgriFood Sector. Agrarwirtschaft, 58(7), 285-293.

Buchenrieder, G. and Möllers, J.(2011). The Transformation of the Rural Economy in the New Member States of the European Union: Implications for Empirical Analyses of Rural Structural Change and Livelihoods. In: M. Judith, B. Gertrud, Csaki Csaba (eds) Structural Change in Agricultural and Rural Livelihoods: Policy Implications for the New Member States of the European Union, IAMO, Vol 61

Drobnjak, M., Kokotović, V., Panić, M.(2015). Transformation of rural space and rural society. In P. Milenković, S. Stojšin, A. Pajvančić Cizelj (eds) Society and Space. Beograd: Srpsko sociološko društvo, Institut za uporedno pravo; Novi Sad: Filozofski fakultet Univerziteta u Novom Sadu, 175-190. [In Serbian]

Happe,K.(2007). Structural Change in Agriculture. In Buchenrieder Gertrud, Möllers Judith, Happe Kathrin, Davidova Sophia, Fredriksson Lena, Bailey Alastair, Gorton Matthew, Kancs d'Artis, Swinnen Johan, Vranken Liesbet, Hubbard Carmen, Ward Neil, Juvančić Luka, Milczarek Dominika, Mishev Plamen Conceptual framework for analyzing structural shange in agriculture and rural livelihood, Disccusion Paper No.113, IAMO

Jelić, S., Jovanović, T. (2010). Sensitive transition points of agriculture. Sociološki pregled, XLIV (4), 595-614. doi:10.5937/socpreg1004595][In Serbian]

Felipe, J. D. (2014). The Declining Share of Agricultural Employment in the People's Republic of China: How Fast? Mandaluyong City: Asian Development Bank.

Šljukić, S. (2004). The social structure in the former socialist countries: Transition or transformation? Sociološki pregled XXXVIII (1-2), 267-279. doi:10.5937/soc preg0402267S. [In Serbian] 
Šljukić, S. (2014). Changes in the social structure and role of the peasantry. Zbornik Matice srpske za društvene nauke, br.146, 71-84. [In Serbian]

Zakić, Z., Stojanović, Ž. (2008). Agrarian economics. Beograd: Centar za izdavačku delatnost Ekonomskog fakulteta. [In Serbian]

ILO .Key Indicators of the Labour Market, 9th edition interactive software.http://kilm.ilo. org

WB. World Development Indicators. data.worldbank.org

WTO. stat.wto.org

OECD Stat http://stats.oecd.org

Bosnia \& Herzegovina, Agency for Statistics www.bhas.ba

Czech Republic, Czech Statistical Office, www.czso.cz

Estonia, Statistics Estonia, www.stat.ee

Republic of Albania, Institute of Statistics, www.instat.gov.al

Republic of Bulgaria, National statistical institute, www.nsi.bg

Republic of Croatia, Croatian Bureau of Statistics, www.dzs.hr

Republic of Romania, National Institute of Statitstics, www.insse.ro

Republic of Serbia, Statistical Office, webrzs.stat.gov.rs

Republic of Slovenia, Statistical Office, www.stat.si

Republic of Macedonia, State Statistical Office www.stat.gov.mk 
Сретен М. Јелић, Вукашин Ж. Коларевић, Значај йољойривреgе у йривреgној...

APPENDIX / ПРИЛОЗИ

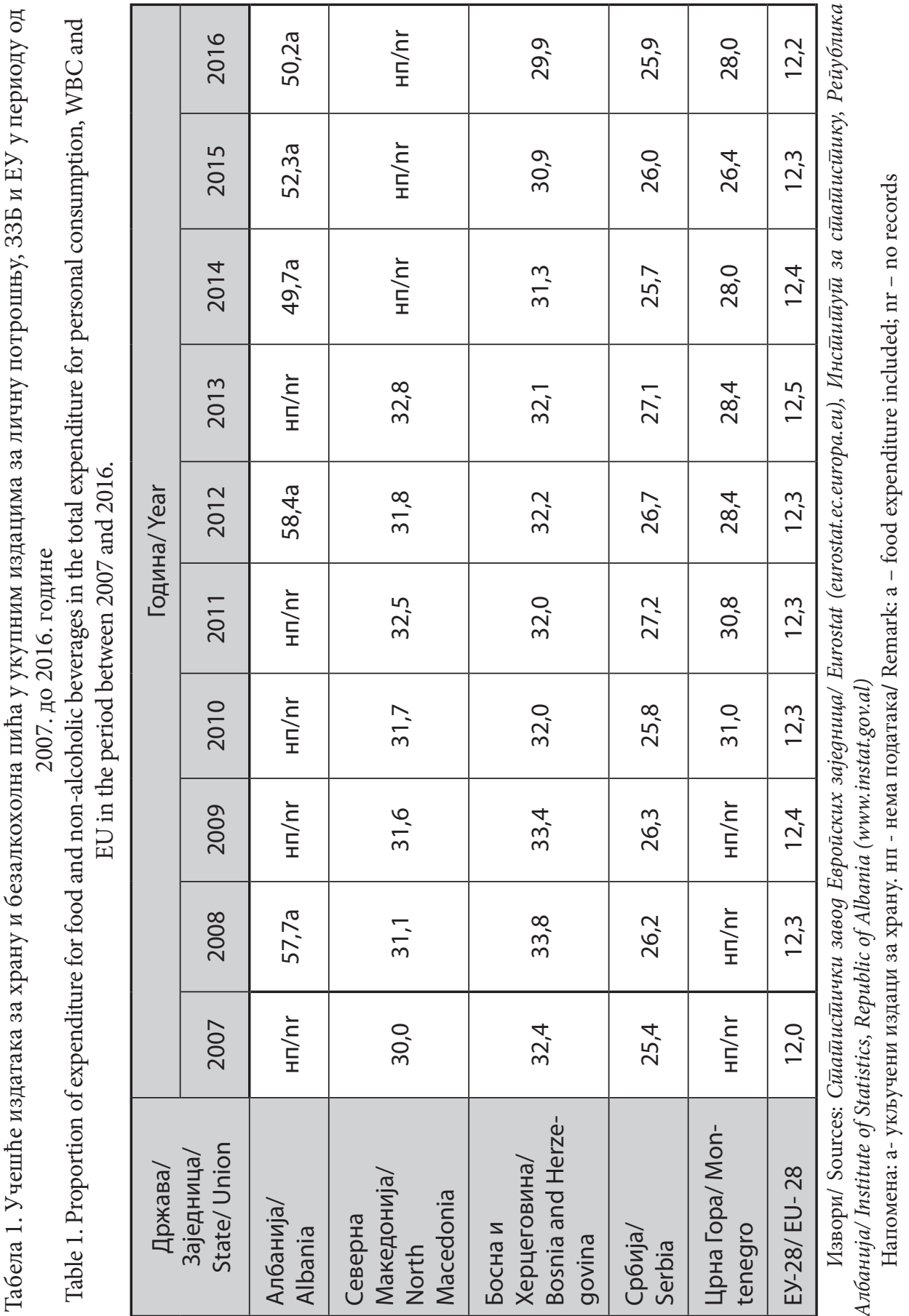


Графикон 1. Учешће запослених у пољопровреди у укупном броју запослених, од 1993. до 2017. године, изражено у процентима/

Graph 1. Proportion of employment in agriculture in the total employment from 1993 to 2017, expressed in percentages.

НАЗАД — BACK
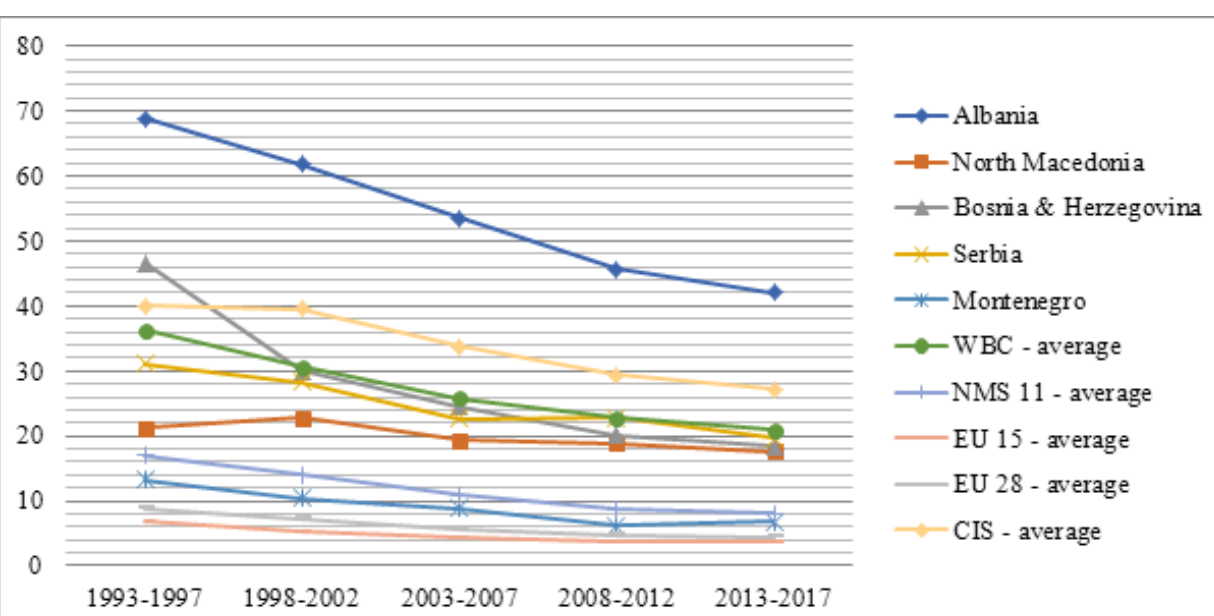

Извор: Показатељи светског развоја, Светска банка/Source: World Development Indicators, World Bank (data.worldbank.org)

Графикон 2. Учешће пољопривреде у формирању бруто домаћег производа (БДП), од 1993. до 2017. године, изражено у процентима/

Graph 2. Proportion of agriculture in gross domestic product (GDP) from 1993 to 2017, expressed in percentages.

НАЗАД

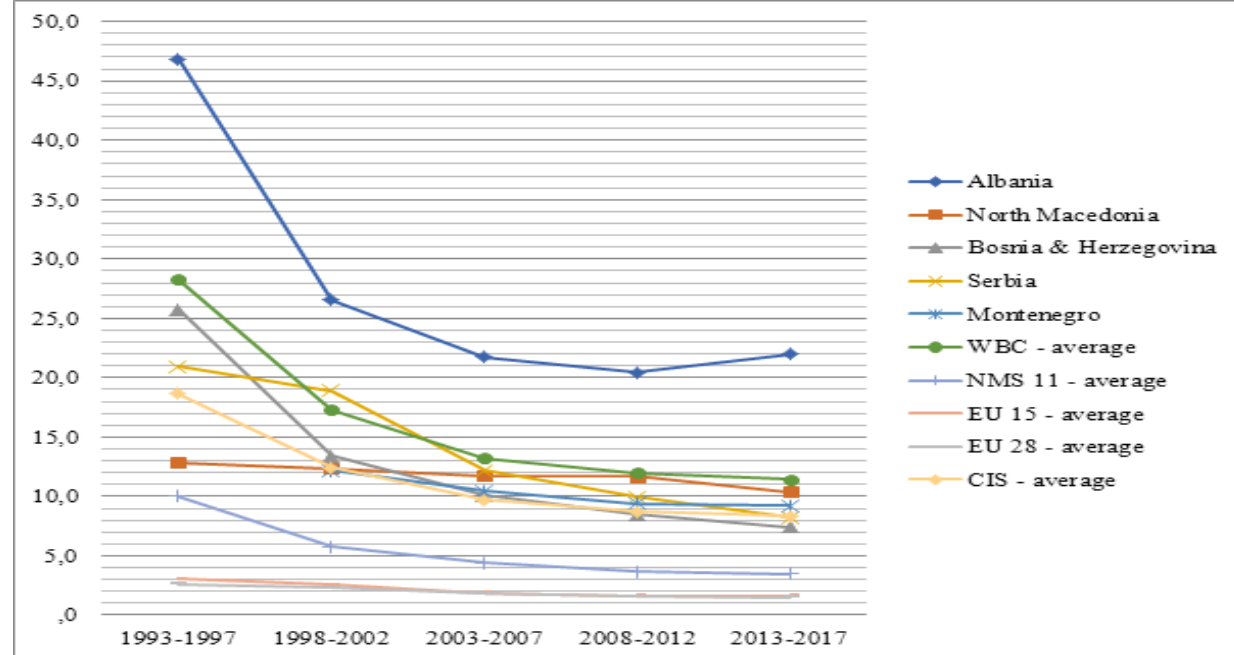

Извор: Показатељи светског развоја, Светска банка/Source: World Development Indicators, World Bank (data.worldbank.org) 
Сретен М. Јелић, Вукашин Ж. Коларевић, Значај йолойривреgе у йривреgној...

Графикон 3.Просечан салдо спољнотрговинске размене пољопривредних производа З3Б у периоду од 1995.до 2014. године (у млрд. \$)/

Graph 3. Average balance of foreign trade of agricultural products in WBC in the period between 1995 and 2014 (billions of \$).

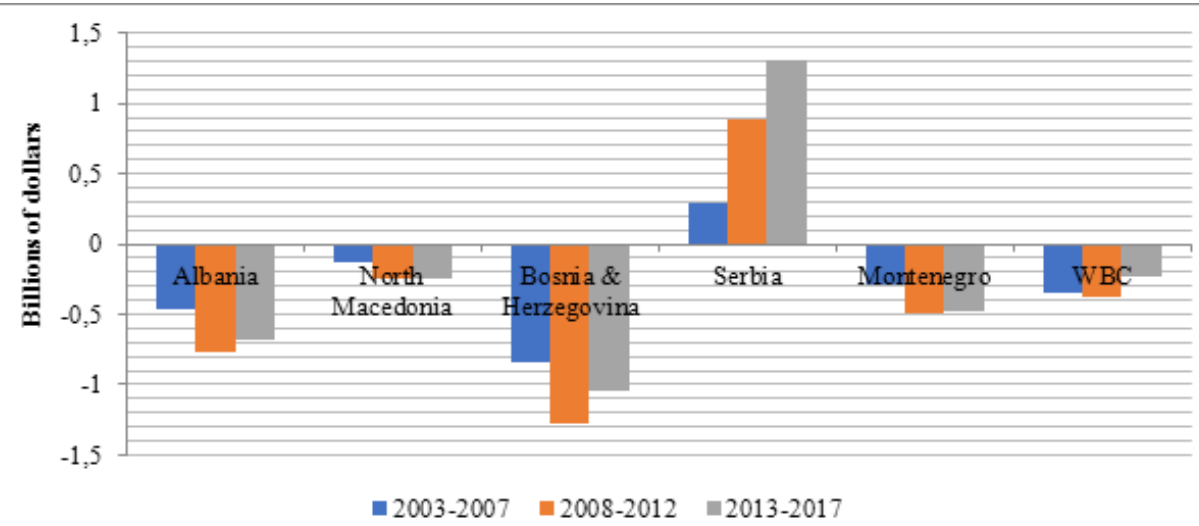

Извор: Светска трговинска организација/ Source: World Trade Organization (stat.wto.org)

Графикон 4. Учешће пољопривреде у укупном извозу З3Б од 2003.до 2017. године, изражено у процентима/

Graph 4. Proportion of agriculture in the total export of WBC in the period between 2003 and 2017, expressed in percentages.

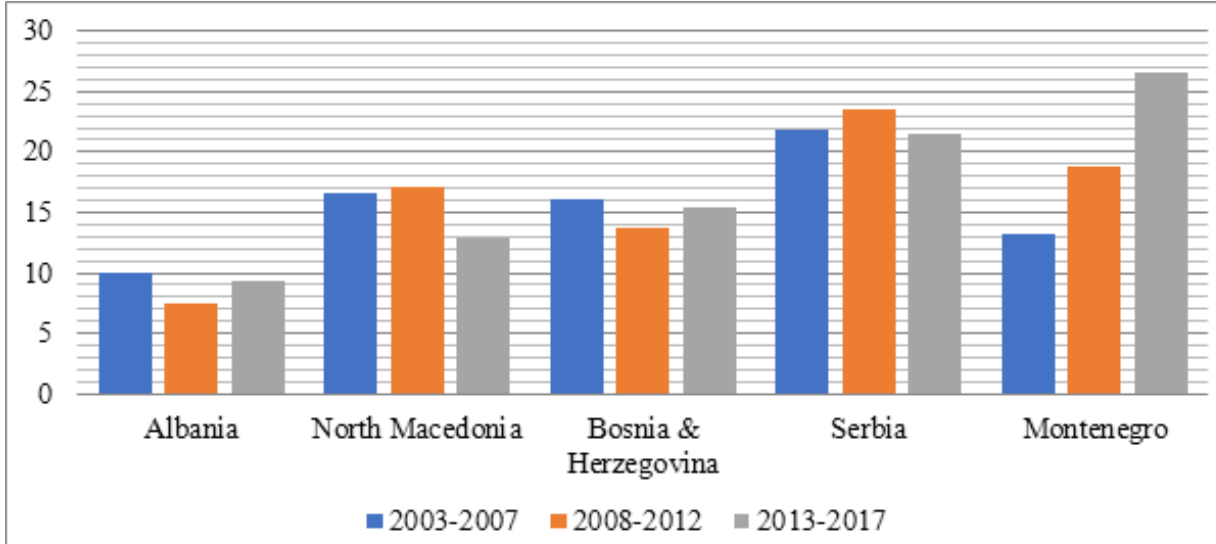

Извор: Светска трговинска организација/ Source: World Trade Organization (stat.wto.org) 
Графикон 5. Заступљеност инвестиција у пољопривреди у укупним привредним инвестицијама у појединим транзиционим земљама од 2005. до 2014. године изражена у процентима (\%)/

Graph 5. Proportion of agricultural investments in total economic investments in certain transition countries in the period between 2005 and 2014, expressed in percentages (\%).

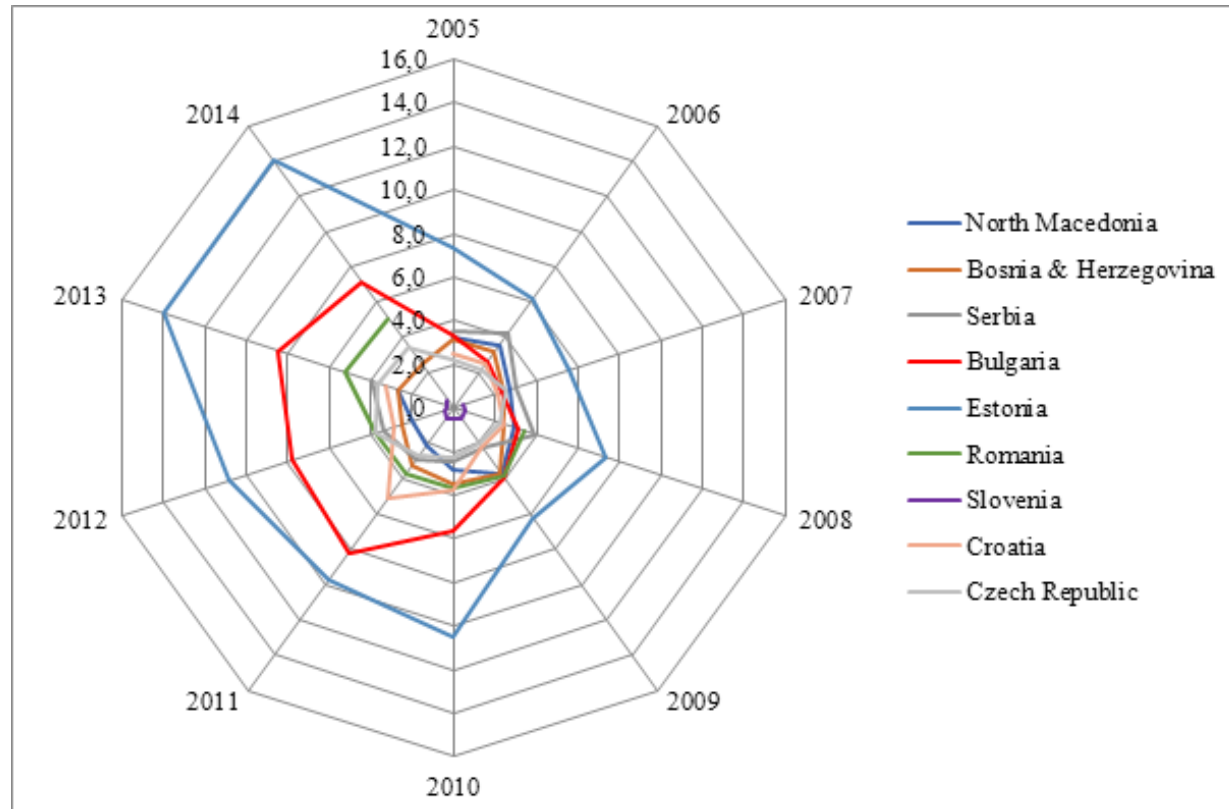

Извори/Sources:

Државни завод за статистику, Република Северна Македонија/ State Statistical Office, Republic of North Macedonia (www.stat.gov.mk);

Агенција за статистику, БиХ/Agency for Statistics, Bosnia \& Herzegovina (www.bhas.ba);

Републички завод за статистику Србије/ Statistical Office, Republic of Serbia (webrzs.stat. gov.rs);

Национални статистички институт, Република Бугарска/ National Statistical Institute, Republic of Bulgaria (www.nsi.bg);

Национални институт за статистику, Република Румунија/ National Institute of Statitstics, Republic of Romania (www.insse.ro);

Државни завод за статистику, Република Хрватска/ Croatian Bureau of Statistics, Republic of Croatia (www.dzs.hr);

Чешки статистички уред, Чешка Република/ Czech Statistical Office, Czech Republic (www.czso.cz);

Естонски уред за статистику, Естонија/ Statistics Estonia, Estonia (www.stat.ee);

Статистички уред Републике Словеније/Statistical Office, Republic of Slovenia, (www.stat.si). 